\title{
Н.Б.Іваха $^{1}{ }^{*}$, О.С.Бережницька ${ }^{1,2}$, О.О.Роговцов ${ }^{1}$, О.К.Трунова ${ }^{1}$ \\ КОМПЛЕКСИ НЕОДИМУ (III) ТА ЕРБіЮ (III) 3 НОВИМИ НЕНАСИЧЕНИМИ $\beta$-ДИКЕТОНАМИ
}

\author{
${ }^{1}$ Інститут загальної та неорганічної хімії ім. В.І.Вернадського НАН Украӥни, \\ просп. Академіка Палладіна, 32/34, Київ, 03142, Україна \\ ${ }^{2}$ Національний технічний університет Украйни "Київський політехнічний \\ інститут імені Ігоря Сікорського”, просп. Перемоги, 37, Київ, 03056, Украӥна \\ *e-mail: ivakhanadiia@gmail.com
}

\begin{abstract}
Синтезовано нові ненасичені $\beta$-дикетони - 2,6-диметил-гептен-1-діон-3,5 (dmhpd) i 2,7диметил-октен-1-діон-3,5 (dmod) та трис-комплекси $\mathrm{Nd}(\mathrm{III})$ та $\mathrm{Er}(\mathrm{III})$ на їх основі. Встановлено склад та будову сполук за допомогою методів елементного аналізу, ІЧ- та електронної спектроскопії, термогравіметрії. Показано, що у всіх синтезованих сполуках лантаніди координують $\beta$-дикетонатні ліганди бідентатно-циклічно, незалежно від будови вуглеводневого замісника, а координаційна сфера центрального атома доповнюється 2 або 3 молекулами води. Зміщення та розщеплення смуг в ЕСП свідчать про некубічну симетрію поля лігандів, а координаційний поліедр сполук відповідає квадратній антипризмі. Визначено нефелоксетичний параметр $\beta$, розраховано сили осциляторів надчутливих $f-f$-переходів, виконано оцінку параметрів ковалентності зв'язку Ln-O. За зростанням ступеня ковалентності $\beta$-дикетонатні комплекси можна розташувати у наступний ряд: $\operatorname{Ln}(\mathrm{dmod})_{3}$ $<\operatorname{Ln}(\mathrm{dmhpd})_{3}<(\mathrm{mphpd})_{3}$.
\end{abstract}

К л ю ч о в і с л о в а: комплекси, ненасичені $\beta$-дикетони, синтез, неодим, ербій, спектральні властивості.

ВСТУП. Одним $з$ важливих і цікавих напрямків сучасної координаційної хімії $є$ синтез, вивчення будови та властивостей координаційних сполук лантанідів, у тому числі їх $\beta$-дикетонатів. Можливість застосування таких комплексів у тій чи іншій області науки і техніки визначається їх фізико-хімічними властивостями. Останні, в свою чергу, обумовлені багатьма факторами, зокрема, характером зв'язку метал -ліганд, електронною конфігурацією центрального атома, природою та розташуванням замісників у ліганді, тобто тими чинниками, що безпосередньо впливають на будову комплексу в цілому.

$\beta$-Дикетонати лантанідів 3 насиченими замісниками вивчаються вже протягом багатьох років та досліджені досить грунтовно [1-3]. В той же час координаційні сполуки $\mathrm{Ln}^{3+} 3$ лігандами, які містять ненасичені замісники в $\alpha$-по- ложенні хелатного кільця, $є$ цікавими і перспективними для їх використаня в якості мономерів у реакціях полімеризації та кополімеризації. Попередні дослідження [4-6] показали, що полімери та кополімери на основі метакроїлацетофеноатів лантанідів як церієвої, так і ітрієвої групи проявляють високі емісійні характеристики та можуть бути застосовані в якості прекурсорів люмінесцентних матеріалів. Проте комплекси $\mathrm{Eu}(\mathrm{III})$ та Sm(III) 3 диметилгептендіоном мають олігомерну будову внаслідок самочинної олігомеризації ліганду ще на етапі синтезу, в результаті чого такі сполуки виявилися непридатними для подальших люмінесцентних досліджень [7].

Тому представляє інтерес розробити методику синтезу мономерного диметилгептендіону та його гомологу - диметилоктендіону, одержати комплекси лантанідів на їх основі, дос-

(C) Н.Б.Іваха, О.С.Бережницька, О.О.Роговцов, О.К.Трунова, 2019 
лідити вплив природи та положення замісника в $\beta$-дикетонатному фрагменті на склад, будову та властивості синтезованих сполук, а також порівняти одержані результати 3 даними для комплексів 3 метакроїлацетофеноном.

Отже, метою даної роботи є синтез ненасичених $\beta$-дикетонів $-2,6$-диметил-гептен-1-діону-3,5 і 2,7-диметил-октен-1-діону-3,5 та ї комплексів з $\mathrm{Nd}(\mathrm{III})$ i $\operatorname{Er}(\mathrm{III})$, встановлення будови та властивостей синтезованих координаційних сполук.

ЕКСПЕРИМЕНТАЛЬНА ЧАСТИНА. ДЛЯ одержання координаційних сполук $\mathrm{Ln}^{3+}$ ( $\mathrm{Ln}=\mathrm{Nd}$, $\mathrm{Er})$ в якості лігандів конденсацією Кляйзена згідно $з$ методикою [8] були синтезовані $\beta$-дикетони з ненасиченими замісниками в $\alpha$-положенні:<smiles>C=C(C)C(=O)CC(O)CC(C)C</smiles>

2,7-диметил-октен-1діон-3,5 (Hdmod)<smiles>C=C(CC(C)C(=C)C)C(C)C</smiles>

2,6-диметил-гептен-1діон-3,5 (Hdmhpd) 2,6-диметил-гептен-1-діон-3,5 синтезовано 3 використанням 3-метилбутанону-2 (розчин 0.5 моль $\left(43 \mathrm{~cm}^{3}\right)$ ) та етилового естеру метакрилової кислоти $\left(0.5\right.$ моль $\left.\left(63 \mathrm{~cm}^{3}\right)\right)$ згідно 3 реакцією:<smiles>C=C(C)C(=CC(=O)C(C)C#N)C(C)=C(C)C(=O)OCC</smiles>

Натрієва сіль dmhpd $\mathrm{C}_{9} \mathrm{H}_{14} \mathrm{O}_{2} \mathrm{Na} \epsilon$ аморфною речовиною блідо-жовтого кольору, $t_{\text {пл }}=$ $205^{\circ} \mathrm{C}$. Вихід кінщевого продукту - 60 г ( 68 \%). Дані елементного аналізу $\mathrm{C}_{9} \mathrm{H}_{14} \mathrm{O}_{2} \mathrm{Na}$, \%: розраховано/знайдено - С 61.02/60.95; Н 7.91/7.85; $\mathrm{Na} 12.99 / 12.90 ;$ ЯMP ${ }^{1} \mathrm{H}\left(\mathrm{CDCl}_{3}\right), \delta$, м.ч.: $1.08-$ $1.14\left(\mathrm{~d}, 6 \mathrm{H}, \mathrm{CH}-\mathrm{CH}_{3}\right) ; 1.90\left(\mathrm{~s}, 1 \mathrm{H}, \mathrm{CH}_{3}\right) ; 3.17$ (s, $\left.2 \mathrm{H}, \mathrm{C}-\mathrm{CH}_{2}\right) ; 3.79(\mathrm{~s}, 1 \mathrm{H}, \mathrm{CH}) ; 4.82(\mathrm{~s}, 1 \mathrm{H},=\mathrm{CH}-$ $\mathrm{C}(\mathrm{O})$; 5.05-5.78 (d, $\left.2 \mathrm{H},=\mathrm{CH}_{2}\right)$.

2,7-диметил-октен-1-діон-3,5 синтезовано зі свіжеперегнаних 4-метилпентанону-2 $\left(50 \mathrm{~cm}^{3}\right)$ та етилового естеру метакрилової кислоти (63 $\mathrm{cm}^{3}$ ) за аналогічною методикою (схема далі).

Haтрісва сіль dmhpd $\mathrm{C}_{10} \mathrm{H}_{16} \mathrm{O}_{2} \mathrm{Na} €$ аморфною речовиною кремового кольору, $t_{\text {пл }}=195^{\circ} \mathrm{C}$.

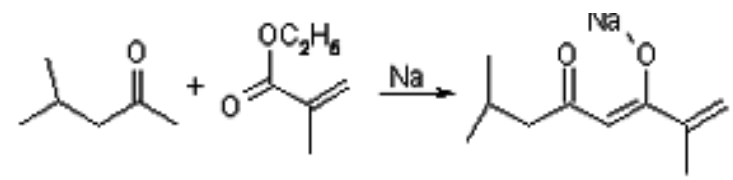

Вихід натрієвої солі - 64 г ( 76\%). Дані елементного аналізу $\mathrm{C}_{10} \mathrm{H}_{16} \mathrm{O}_{2} \mathrm{Na}$, \%: розраховано/знайдено - С 71.40/71.43; Н 10.02/9.85; Na 13.62/13.69; ЯМР ${ }^{1} \mathrm{H}\left(\mathrm{CDCl}_{3}\right), \delta$ м.ч.: $1.10-1.21$ $\left(\mathrm{d}, 6 \mathrm{H}, \mathrm{CH}-\mathrm{C}_{3}\right) ; 2.02\left(\mathrm{~s}, 1 \mathrm{H}, \mathrm{C}_{3}\right) ; 3.21(\mathrm{~s}, 2 \mathrm{H}$, C- $\left.\mathrm{CH}_{2}\right) ; 3.79-3.81\left(\mathrm{~d}, 2 \mathrm{H}, \mathrm{CH}-\mathrm{CH}_{2}\right) ; 3.91(\mathrm{~s}, 1 \mathrm{H}$, $\mathrm{CH}) ; 5.05\left(\mathrm{~s}, 1 \mathrm{H},=\mathrm{CH}-\mathrm{C}(\mathrm{O}) ; 5.41-5.86\left(\mathrm{~d}, 2 \mathrm{H},=\mathrm{CH}_{2}\right)\right.$.

Синтез комплексів Ln(III) з $\beta$-дикетонами проводили взаємодією водних розчинів нітрату неодиму $\left(\mathrm{Nd}\left(\mathrm{NO}_{3}\right)_{3} \cdot 6 \mathrm{H}_{2} \mathrm{O}\right.$, ч.д.а.) або хлориду ербію $\left(\mathrm{ErCl}_{3} \cdot 4 \mathrm{H}_{2} \mathrm{O}\right.$ ч.д.а.) 3 водно-спиртовим розчином натрієвої солі відповідного ліганду при мольному співвідношенні реагентів 1:3.5 (pH 88.5) за кімнатної температури:

$$
\mathrm{Ln}^{3+}+3 \mathrm{NaL} \longrightarrow \mathrm{LnL}_{3}+3 \mathrm{Na}^{+},
$$

де $\mathrm{Ln}(\mathrm{III})=\mathrm{Nd}, \mathrm{Er} ; \mathrm{L}=\mathrm{dmhpd}$, dmod.

Одержані осади комплексів відокремлювали від маточного розчину центрифугуванням, п'ятикратно промивали водою та висушували у вакуумному ексикаторі над безводним $\mathrm{CaCl}_{2}$. Синтезовані комплекси на основі обох $\beta$-дикетонів представляють собою аморфні порошки блідо-рожевого кольору для комплексів ербію та блідо-бузкового - для неодимових сполук, що обумовлено забарвленням відповідних центральних атомів.

При проведенні синтезу та очистки $\beta$-дикетонів 3 ненасиченими замісниками та координаційних сполук на їх основі необхідно суворо дотримуватися температурного режиму, оскільки при підвищенні температури може відбуватися часткова олігомеризація сполук, що значно погіршує їх розчинність та унеможливлює подальше дослідження фізико-хімічних властивостей та застосування.

Елементний аналіз на вміст металу в комплексах проводили на приладі ICPE 9000 фipми Shimadzu (знайдено/розраховано, \% Nd: 20.38/ 20.51 для $\left[\mathrm{Nd}(\mathrm{dmod})_{3} \cdot 2 \mathrm{H}_{2} \mathrm{O}\right] \cdot \mathrm{H}_{2} \mathrm{O} ; 21.75 / 21.82$ для $\left[\mathrm{Nd}(\mathrm{dmhd})_{3} \cdot 2 \mathrm{H}_{2} \mathrm{O}\right] \cdot \mathrm{H}_{2} \mathrm{O} ; \%$ Er: 23.71/23.84 для $\mathrm{Er}(\mathrm{dmod})_{3} \cdot 2 \mathrm{H}_{2} \mathrm{O} ; 25.43 / 25.49$ для $\left.\mathrm{Er}(\mathrm{dmhd})_{3} \cdot 2 \mathrm{H}_{2} \mathrm{O}\right)$. 
Комплекси неодиму (III) та ербію (III) з новими ненасиченими $\beta$-дикетонами

Т а б л и ц 1

Характеристичні частоти в IЧ-спектрах комплексів $\operatorname{Nd}(\mathrm{III})$ та $\operatorname{Er}(\mathrm{III})$ з $\beta$-дикетонами $\left(\mathrm{cm}^{-1}\right)$

\begin{tabular}{c|c|c|c|c|c}
\hline \hline Комплекс & $v(\mathrm{M}-\mathrm{O})+\delta_{\text {хел. кільця }}$ & $v_{a \mathrm{~s}}(\mathrm{C}=-\mathrm{C})$ & $v_{\mathrm{s}}(\mathrm{C}=-\mathrm{O})$ & $v(\mathrm{C}=\mathrm{O})$ & $v_{\mathrm{s}}(\mathrm{C}=\mathrm{C})$ \\
\hline $\mathrm{Na}(\mathrm{mphpd})$ & - & 1568 & - & 1726 & 1670 \\
Nadmhd & - & 1565 & - & 1724 & 1655 \\
Nadmod & - & 1558 & - & 1715 & 1645 \\
{$\left[\mathrm{Nd}(\mathrm{mphpd})_{3} \cdot 2 \mathrm{H}_{2} \mathrm{O}\right] \cdot \mathrm{H}_{2} \mathrm{O}[11]$} & $422,455,486,510,555$ & 1555 & 1595 & - & 1655 \\
$\mathrm{Er}(\mathrm{mphpd})_{3} \cdot 2 \mathrm{H}_{2} \mathrm{O}[11]$ & $414,438,455,470,556$ & 1556 & 1597 & - & 1650 \\
{$\left[\mathrm{Nd}(\mathrm{dmhd})_{3} \cdot 2 \mathrm{H}_{2} \mathrm{O}\right] \cdot \mathrm{H}_{2} \mathrm{O}$} & $422,455,486,510,555$ & 1550 & 1579 & - & 1645 \\
$\mathrm{Er}(\mathrm{dmhd})_{3} \cdot 2 \mathrm{H}_{2} \mathrm{O}$ & $414,438,455,470,556$ & 1541 & 1577 & - & 1640 \\
{$\left[\mathrm{Nd}(\mathrm{dmod})_{3} \cdot 2 \mathrm{H}_{2} \mathrm{O}\right] \cdot \mathrm{H}_{2} \mathrm{O}$} & $412,418,436,452,469$, & 1556 & 1594 & - & 1657 \\
$\operatorname{Er}(\mathrm{dmod})_{3} \cdot 2 \mathrm{H}_{2} \mathrm{O}$ & $484,501,517,550$ & & & - & 1642 \\
\hline \hline
\end{tabular}

Спектри ЯМР ${ }^{1} \mathrm{H}$ записано на спектрометрі Bruker Avance 400 з робочою частотою 400 МГц при $202{ }^{\circ} \mathrm{C}$ у дейтерованому хлороформі (розчинник). Положення сигналів у спектрах визначено відносно тетраметилсилану як внутрішнього стандарту, експериментальна точність величини хімічного зсуву $\delta$ складала 0.001 м.ч.

Гідратний склад комплексів та їх термічні характеристики встановлено методом ДТА. Термограми записували на дериватографі Q-1500 ${ }^{\circ} \mathrm{D}$ системи F.Paulik-J.Paulik-L.Erdey в інтервалі температур $20-500{ }^{\circ} \mathrm{C}$ зі швидкістю нагріву $5^{\circ} \mathrm{C} /$ хв у платиновому тиглі за присутності носія (безводного $\mathrm{Al}_{2} \mathrm{O}_{3}$ ).

ІЧ-спектри записували на спектрометрі Specord M80 в області $400-4000 \mathrm{~cm}^{-1}$ у таблетках $3 \mathrm{KBr}$. Спектри дифузного відбиття в області 300-1100 нм реєстрували на спектрофотометpi UV-VIS-IR Shimadzu UV-3600.

ОБГОВОРЕННЯ РЕЗУЛЬТАТІВ. Дані про скЛад та будову комплексних сполук можуть бути отримані при вивченні їх ІЧ-спектрів, оскільки кількість, інтенсивність коливань та їх положення строго визначені симетрією досліджуваного комплексу. Віднесення коливальних частот в ІЧ-спектрах комплексів $\mathrm{Nd}(\mathrm{III})$ та $\mathrm{Er}(\mathrm{III})$ 3 синтезованими ненасиченими $\beta$-дикетонами (табл. 1) проводили, спираючись на літературні дані [9].

Відомо [10], що відсутність у $\beta$-дикетонатних комплексах інтенсивних смуг коливан- ня, характерних для $\mathrm{v}(\mathrm{C}=\mathrm{O})$ вільного $\beta$-дикетона $\left(1750-1650 \mathrm{~cm}^{-1}\right)$, та поява інтенсивних смуг в області більш низьких частот (1597-1541 $\mathrm{cm}^{-1}$ ) вказує на бідентатну координацію ліганду атомами оксигену карбонільних груп до центрального іона $\mathrm{Ln}^{3+}$. Причому смуга 3 вищою частотою відповідає симетричному валентному коливанню зв'язку $(\mathrm{C}=-\mathrm{O})$, а 3 меншою - асиметричному валентному коливанню зв'язку $(\mathrm{C}=-\mathrm{C})$. Положення цих смуг у спектрах $\beta$-дикарбонільних комплексів свідчить про наявність спряження у $\beta$-дикетонатному кільці, внаслідок чого частоти смуг поглинань $\epsilon$ проміжними між характеристичними частотами коливань подвійних та одинарних зв'язків СО та СС.

Для $\beta$-дикетонатних координаційних сполук 3 ненасиченими замісниками характерна наявність смуги невисокої інтенсивності в області 1670-1630 см-1, яка відповідає валентному коливанню подвійного зв'язку $\mathrm{C}=\mathrm{C}$. Оскільки для досліджуваних $\beta$-дикетонатних комплексів ця смуга спостерігається при 1645 ([Nd$\left.\left.(\mathrm{dmhd})_{3} \cdot 2 \mathrm{H}_{2} \mathrm{O}\right] \cdot \mathrm{H}_{2} \mathrm{O}\right), 1640\left(\mathrm{Er}(\mathrm{dmhd})_{3} \cdot 2 \mathrm{H}_{2} \mathrm{O}\right)$, $1657\left(\left[\mathrm{Nd}(\mathrm{dmod})_{3} \cdot 2 \mathrm{H}_{2} \mathrm{O}\right] \cdot \mathrm{H}_{2} \mathrm{O}\right)$ та $1642 \mathrm{~cm}^{-1}$ $\left(\mathrm{Er}(\mathrm{dmod})_{3} \cdot 2 \mathrm{H}_{2} \mathrm{O}\right)$, можна стверджувати, що синтезовані сполуки є ненасиченими. Смуги, які спостерігаються в ІЧ-спектрах $\beta$-дикетонатних комплексів в області 600-400 $\mathrm{cm}^{-1}$, слід віднести до комбінації валентних коливань зв'язку метал-оксиген 3 деформаційними коливання- 
Н.Б.Іваха, О.С.Бережницька, О.О.Роговиов, О.К.Трунова

Т а б л и ц 2

Термічна стійкість $\beta$-дикетонатів Nd(III) та $\operatorname{Er}(\mathrm{III})$

\begin{tabular}{|c|c|c|c|c|c|c|}
\hline \multirow{3}{*}{ Сполука } & \multicolumn{4}{|c|}{ Процес дегідратації } & \multirow{2}{*}{\multicolumn{2}{|c|}{$t_{\text {деструкції }}{ }^{\circ} \mathrm{C}$}} \\
\hline & \multirow{2}{*}{$t,{ }^{\circ} \mathrm{C} /$ термоефект } & \multicolumn{2}{|c|}{$\Delta m, \%$} & \multirow{2}{*}{$n\left(\mathrm{H}_{2} \mathrm{O}\right)$} & & \\
\hline & & розраховано & знайдено & & $t_{\text {Поч }}$ & $t_{\text {кінц }}$ \\
\hline$\left[\mathrm{Nd}(\mathrm{dmhpd})_{3} \cdot 2 \mathrm{H}_{2} \mathrm{O}\right] \cdot \mathrm{H}_{2} \mathrm{O}$ & 150/ендо & 8.7 & 8.7 & 3 & 255 & 500 \\
\hline $\mathrm{Er}(\mathrm{dmhpd})_{3} \cdot 2 \mathrm{H}_{2} \mathrm{O}$ & 135/ендо & 5.4 & 5.5 & 2 & 300 & 465 \\
\hline$\left[\mathrm{Nd}(\mathrm{dmod})_{3} \cdot 2 \mathrm{H}_{2} \mathrm{O}\right] \cdot \mathrm{H}_{2} \mathrm{O}$ & 123/ендо & 7.7 & 7.75 & 3 & 270 & 500 \\
\hline $\mathrm{Er}(\mathrm{dmod})_{3} \cdot 2 \mathrm{H}_{2} \mathrm{O}$ & 125/ендо & 5.1 & 5.25 & 2 & 290 & 480 \\
\hline
\end{tabular}

ми хелатного кільця, що є додатковим підтвердженням утворення комплексів. Необхідно зазначити, що у високочастотній області спектру (3600-3200 $\mathrm{cm}^{-1}$ ) для всіх комплексів спостерігається широка смуга, яка свідчить про наявність у складі комплексів молекул води.

ІЧ-спектри досліджуваних комплексів неодиму та ербію 3 диметилгептендіоном та диметилоктендіоном ідентичні до раніше описаних нами $\beta$-дикетонатів лантанідів [11].

Для дослідження процесів дегідратації та розкладу $\beta$-дикетонатних комплексів $3 \mathrm{Ln}^{3+}$ проведено термогравіметричний аналіз в інтервалі температур $20-500{ }^{\circ} \mathrm{C}$ (табл. 2).

Як відомо з літературних джерел [12], лантаніди початку ряду часто утворюють стійкі тригідрати, в той час як елементи кінця ряду - моногідрати. Аналізуючи криві ДТА та TG, можна сказати, що починаючи від $75^{\circ} \mathrm{C}$ для диметилоктендіонового комплексу $\mathrm{Nd}$ (III) та від $95^{\circ} \mathrm{C}$ - для диметилгептендіонату неодиму відбувається ступінчате відщеплення спочатку однієї молекули води, а в інтервалі температур $120-160^{\circ} \mathrm{C}-$ двох молекул $\mathrm{H}_{2} \mathrm{O}$.

3 літературних даних дослідження комплексів металів з ненасиченими $\beta$-дикетонами [13] відомо, що адсорбована вода відщеплюється при $70-85^{\circ} \mathrm{C}$, а при значно вищих (як правило, $120-150^{\circ} \mathrm{C}$ ) температурах відбувається видалення координованих молекул води. Тому можна стверджувати, що в досліджуваних комплексах $\mathrm{Nd}$ (III) дві молекули води входять до внутрішньої координаційної сфери, а одна молекула є адсорбованою.
Подальший нагрів зразків приводить до полімеризації сполук без ініціатора, про що свідчать екзоефекти при $225^{\circ} \mathrm{C}$. За температур вище $300{ }^{\circ} \mathrm{C}$ руйнується органічна частина комплексів, що супроводжується інтенсивними екзоефектами.

У випадку ербієвих комплексів як з диметилгептендіоном, так і 3 диметилоктендіоном в області температур $120-140^{\circ} \mathrm{C}$ відбувається процес дегідратації комплексів, який протікає в одну стадію з ендотермічним ефектом. Вміст води, розрахований по втраті маси зразка, відповідає наявності в складі комплексів двох молекул води. Подальше руйнування комплексів ербію проходить аналогічно до описаних вище сполук неодиму.

Загальна втрата маси становить 65-75\% до $500{ }^{\circ} \mathrm{C}$. Виходячи 3 термогравіметричних даних, можна стверджувати, що синтезовані ненасичені $\beta$-дикетонати неодиму та ербію $є$ нелеткими та розкладаються 3 утворенням відповідних оксидів.

Таким чином, сукупність результатів термічного та IЧ-аналізу показали, що іон Ln(III) координує три молекули $\beta$-дикетону, до внутрішньої координаційної сфери комплексів входять 2 молекули води, а їх склад відповідає формулам $\left[\mathrm{Nd}(\beta \text {-dik })_{3} \cdot 2 \mathrm{H}_{2} \mathrm{O}\right] \cdot \mathrm{H}_{2} \mathrm{O}$ та $\mathrm{Er}(\beta \text {-dik) })_{3} \cdot 2 \mathrm{H}_{2} \mathrm{O}$. Схематично будову трис-комплексів лантанідів $3 \beta$-дикетонами можна зобразити наступною схемою (схема далі).

Оцінку геометрії, координаційного числа та встановлення симетрії найближчого координаційного оточення іона $\operatorname{Ln}($ III) проведено 


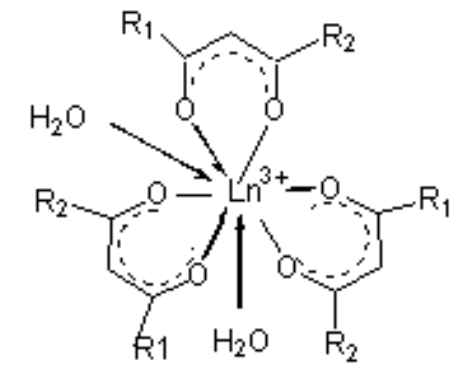

$\mathrm{R}_{2}-\mathrm{C}=\left(\mathrm{CH}_{2}\right)\left(\mathrm{CH}_{3}\right) ; \mathrm{R}_{1}=-\mathrm{CH}\left(\mathrm{CH}_{3}\right)_{2},-\mathrm{CH}_{2} \mathrm{CH}\left(\mathrm{CH}_{3}\right)_{2}$.

на основі аналізу положення та інтенсивності смуг поглинання $f$-f-переходів в електронних спектрах поглинання досліджуваних сполук та співставленням $з$ літературними даними щодо аналогічних сполук [14-16]. Враховуючи, що при розчиненні склад комплексів може змінюватись за рахунок взаємодії з розчинником чи дисоціації комплексів, записували також спектри дифузного відбиття синтезованих $\beta$-дикетонатів металів.

На рис. 1 наведено СДВ комплексу неодиму 3 диметилоктендіоном, в якому спостерігається набір смуг, який відповідає $f$-f-переходам іона $\mathrm{Nd} 3$ основного стану ${ }^{4} I_{9 / 2}$. Для розгляду впливу поля лігандів найчастіше вибирають смуги надчутливих переходів (НЧП), якими для $\mathrm{Nd}^{3+} \epsilon^{4} I_{9 / 2} \rightarrow{ }^{2} P_{1 / 2},{ }^{4} I_{9 / 2} \rightarrow{ }^{2} \mathrm{G}_{7 / 2}$, ${ }^{4} G_{5 / 2}$. У комплексах ці смуги можуть зазнавати зміщення під впливом кристалічного по-

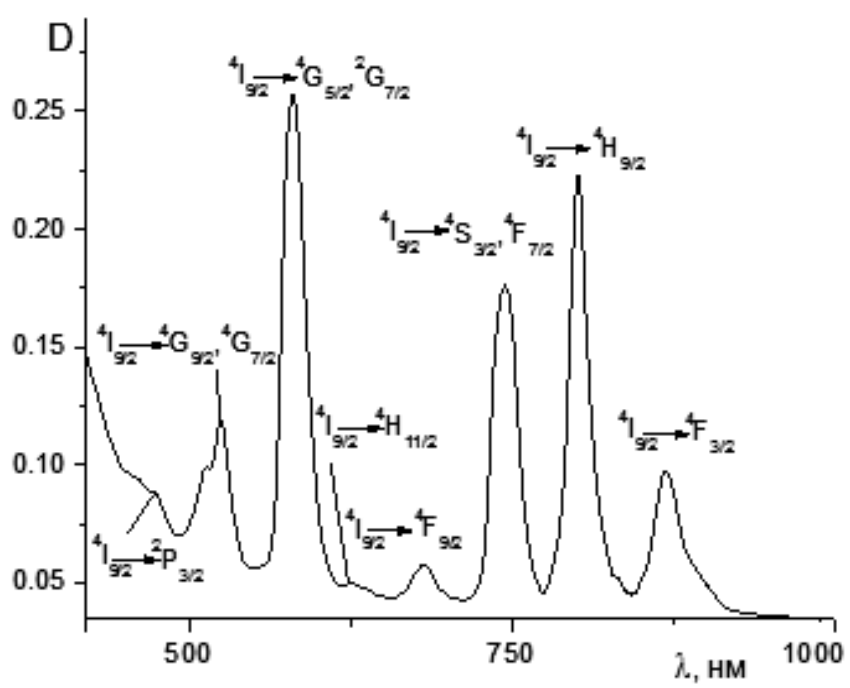

Рис. 1. СДВ комплексу $\left[\mathrm{Nd}(\mathrm{dmod})_{3} \cdot 2 \mathrm{H}_{2} \mathrm{O}\right] \cdot \mathrm{H}_{2} \mathrm{O}$. ля лігандів і за величиною відхилення можна оцінювати внесок іонної складової у зв' язок метал-ліганд. Вивчення розщеплення в спектрах поглинання дозволяє одержати певні відомості про геометрію внутрішньої координаційної сфери комплексу. За кількістю підрівнів розщеплення можна визначати його симетрію, а по величині розщеплення - силу поля лігандів [17]. У відповідності до електростатичних уявлень найбільше розщеплення викликають ліганди 3 великим негативним зарядом i ті, що здатні досить близько підійти до іона металу, тобто невеликі іони, у випадку наших лігандів це 2,6-диметилгептендіон.

У СДВ для диметилоктендіонатного комплексу неодиму (рис. 1 , табл. 3 ) смуга ${ }^{4} I_{9 / 2} \rightarrow{ }^{2} P_{1 / 2}$ $\left(\lambda_{\max }=427\right.$ нм $) \epsilon$ синглетною, що свідчить про наявність одного оптичного центра у твердому зразку. В спектрі поглинання $\mathrm{Nd}(\mathrm{dmod})_{3} \cdot 2 \mathrm{H}_{2} \mathrm{O}$ напівширина надчутливих переходів ${ }^{4} I_{9 / 4} \rightarrow$ ${ }^{4} G_{5 / 2},{ }^{2} G_{7 / 2}$ становить +242 та $-349 \mathrm{~cm}^{-1}$ відповідно, а смуга ${ }^{4} I_{9 / 4} \rightarrow{ }^{2} \mathrm{G}_{7 / 2}$ містить плече, що властиво для сполук з досить високою симетрією.

На відміну від $\mathrm{Nd}(\mathrm{dmod})_{3} \cdot 2 \mathrm{H}_{2} \mathrm{O}$ в СДВ комплексу $\mathrm{Nd}(\mathrm{dmhpd})_{3} \cdot 2 \mathrm{H}_{2} \mathrm{O}$ смуга переходу ${ }^{4} I_{9 / 2}$ $\rightarrow{ }^{2} P_{1 / 2}$ розщеплена на 2 компоненти, що може свідчити про існування двох оптичних центрів.

Батохромне зміщення максимуму даної смуги відносно $\mathrm{Nd}_{\mathrm{aq}}{ }^{3+}$ складає $131 \mathrm{~cm}^{-1}$, а напівширина НЧП ${ }^{4} I_{9 / 4} \rightarrow{ }^{4} G_{5 / 2},{ }^{2} G_{7 / 2}$ становить (+255 та $-359 \mathrm{~cm}^{-1}$ ) відповідно, причому смуга ${ }^{4} I_{9 / 4}$ $\rightarrow{ }^{2} G_{7 / 2}$ розщеплена на дві компоненти. Довгохвильове зміщення смуг поглинання НЧП для комплексів неодиму відносно їх положення в спектрі акваіона та розщеплення спектральних ліній на декілька компонент (3 для переходу ${ }^{4} I_{9 / 4} \rightarrow{ }^{2} S_{3 / 2}{ }_{4}^{4} F_{7 / 2}, 6-$ для переходу ${ }^{4} I_{9 / 2} \rightarrow{ }^{4} G_{5 / 2}$ та 4 - для ${ }^{4} I_{9 / 4} \rightarrow{ }^{4} F_{3 / 2}$ ) може свідчити про некубічну симетрію поля лігандів.

Збільшення інтенсивності всіх смуг поглинання комплексів неодиму та їх батохромний зсув порівняно зі спектрами аква-іона (табл. 3) свідчить про утворення комплексів. Форма та положення смуг в ЕСДВ комплексів $\mathrm{Nd}(\mathrm{dmod})_{3}$. $2 \mathrm{H}_{2} \mathrm{O}$ та $\mathrm{Nd}(\mathrm{dmhpd})_{3} \cdot 2 \mathrm{H}_{2} \mathrm{O}$ в області надчутливих переходів ${ }^{4} I_{9 / 2} \rightarrow{ }^{4} G_{5 / 2},{ }^{2} G_{7 / 2}$ неодиму та аналіз літературних джерел [19] дозволяють 
Т а б ли ц я 3

Енергії переходів в електронних спектрах поглинання комплексів неодиму (III), см

\begin{tabular}{c|c|c|c|c}
\hline \hline Перехід & $\mathrm{Nd}_{\text {aq }}{ }^{3+}$ & $\begin{array}{c}\mathrm{Nd}(\mathrm{mphpd})_{3} \\
{[18]}\end{array}$ & $\mathrm{Nd}(\mathrm{dmod})_{3}$ & $\mathrm{Nd}(\mathrm{dmhpd})_{3}$ \\
\hline${ }^{4} I_{9 / 2} \rightarrow{ }^{2} P_{1 / 2}$ & 23064 & 23255 & 23195 & 23101 \\
${ }^{4} I_{9 / 2} \rightarrow{ }^{4} G_{9 / 2}$ & 19560 & 19520 & 19520 & 19450 \\
${ }^{4} I_{9 / 2} \rightarrow{ }^{4} G_{7 / 2}$ & 19157 & 19050 & 19050 & 18975 \\
${ }^{4} I_{9 / 2} \rightarrow{ }^{4} G_{5 / 2},{ }^{2} G_{7 / 2}$ & 17360 & 17168 & 17150 & 17162 \\
${ }^{4} I_{9 / 2} \rightarrow{ }^{4} F_{9 / 2}$ & 14720 & 14700 & 14650 & 14610 \\
${ }^{4} I_{9 / 2} \rightarrow{ }^{4} F_{7 / 2}$ & 13513 & 13400 & 13320 & 13440 \\
${ }^{4} I_{9 / 2} \rightarrow{ }^{4} H_{9 / 2}$ & 12594 & 12470 & 12470 & 12460 \\
${ }^{4} I_{9 / 2} \rightarrow{ }^{4} \mathrm{~F}_{3 / 2}$ & 11560 & 11430 & 11430 & 11420 \\
\hline \hline
\end{tabular}

${ }^{4} H_{11 / 2}(522$ та $521 \mathrm{Hм}),{ }^{4} F_{9 / 2}(653$ та $652 \mathrm{HM}),{ }^{4} I_{9 / 2}(802$ та $801 \mathrm{HM})$.

У спектрах металокомплексів смуги розщеплені під дією кристалічного поля ліганду та зміщені на 50-250 $\mathrm{cm}^{-1}$ у довгохвильову область відносно аква-іона (табл. 4), що свідчить про певний внесок ковалентної складової у цей зв'язок [20]. Крім того, це може вказувати на утворення комплексів 3 більшим координаційним числом, ніж у неорганічної солі ербію [21], оскільки відомо, що для координаційних сполук ербію здебільшого спостерігається короткохвильове зміщення смуг поглинання, що обумовлено зменшенням координаційного числа центрального іона.

Виходячи $з$ отриманих в роботі результатів та співставлення їх 3 попередніми дослідженнями, слід зазначити, що форма спектрів та спектральне розщеплення смуг для комплексів ербію 3 різними ненасиченими $\beta$-дикетонами суттєво не відрізняється, що дозволяє зробити висновок про близькість координаційного оточення іона $\operatorname{Er}(\mathrm{III})$ у $\beta$-дикетонатних сполуках. Для смуг НЧП обох лантанідів $\left({ }^{4} I_{9 / 2} \rightarrow{ }^{2.4} G_{7 / 2, \text { y } 5 / 2-\text { для Nd }}{ }^{3+},{ }^{4} I_{15 / 2}\right.$ $\rightarrow{ }^{4} \mathrm{G}_{11 / 2}-$ для $\mathrm{Er}^{3+}$ ) розраховані параметри ковалентності зв'язку: нефелоксетичний параметр $\beta$, параметр ковалентності $b^{1 / 2}$, параметр Sinha- $\delta$ та сили осциллятора $P$ (табл. 5) [22]. 3 таблиці видно, що зменшення параметрів ковалентності $\left(b^{1 / 2}\right.$ i $\left.\delta\right)$ та зростання нефелоксетичного параметра $\beta$ для комплексів ербію у порівнянні з координаційними сполуками неодиму свідчать про зростання ковалентності зв'язку металу 3 лігандом у відповідності до правила Панета-Фаянса. Така зміна ковалентної складової у зв'язку лантанід-ліганд обумовлена як зменшенням іонного радіусу внаслідок лантанідного стискання, так і скороченням відстані Ln-O [21]. Виходячи 3

Рис. 2. СДВ комплексів ербію 3 диметилоктендіоном. 
Т аб ли ц я 4

Енергії переходів у СДВ комплексів $\operatorname{Er}\left(\right.$ III), см$^{-1}$

\begin{tabular}{c|c|c|c|c}
\hline \hline Перехід & $\mathrm{Er}^{3+}$ & $\begin{array}{c}\text { Er(mphpd })_{3} \cdot \\
2 \mathrm{H}_{2} \mathrm{O}[18]\end{array}$ & $\begin{array}{c}\operatorname{Er}(\mathrm{dmod})_{3} \cdot \\
2 \mathrm{H}_{2} \mathrm{O}\end{array}$ & $\begin{array}{c}\mathrm{Er}(\mathrm{dmhpd})_{3} . \\
2 \mathrm{H}_{2} \mathrm{O}\end{array}$ \\
\hline${ }^{4} I_{15 / 2} \rightarrow{ }^{2} D_{5 / 2}$ & 38897 & & - & 38240 \\
${ }^{4} I_{15 / 2} \rightarrow{ }^{2} G_{9 / 2}$ & 27629 & & - & 27410 \\
${ }^{4} I_{15 / 2} \rightarrow{ }^{2} G_{11 / 2}$ & 26585 & 26455 & 26309 & 26420 \\
${ }^{4} I_{15 / 2} \rightarrow\left({ }^{2} G, F\right)_{9 / 2}$ & 24744 & & 24520 & 24530 \\
${ }^{4} I_{15 / 2} \rightarrow{ }^{4} F_{5 / 2}$ & 22378 & & 22270 & 22296 \\
${ }^{4} I_{15 / 2} \rightarrow{ }^{4} F_{7 / 2}$ & 20709 & 20576 & 20538 & 20490 \\
${ }^{4} I_{15 / 2} \rightarrow{ }^{2} H_{11 / 2}$ & 19334 & 19231 & 19190 & 19157 \\
${ }^{4} I_{15 / 2} \rightarrow{ }^{4} S_{3 / 2}$ & 18570 & & 18450 & 18400 \\
${ }^{4} I_{15 / 2} \rightarrow{ }^{4} F_{9 / 2}$ & 15452 & 15337 & 15324 & 15313 \\
${ }^{4} I_{15 / 2} \rightarrow{ }^{4} I_{9 / 2}$ & 12567 & 12500 & 12488 & 12477 \\
\hline \hline
\end{tabular}

Т а б ли ц я 5

Параметри ковалентності комплексів $\operatorname{Ln}(\beta-d i k)_{3} \cdot 2 \mathrm{H}_{2} \mathrm{O}$

\begin{tabular}{c|c|c|c|c|c}
\hline \hline $\begin{array}{c}\mathrm{Ln}(\beta \text {-dik })_{3} \cdot \\
2 \mathrm{H}_{2} \mathrm{O}\end{array}$ & Перехід & $P_{\text {осц }} \cdot 10^{6}$ & $\beta$ & $\delta$ & $b^{1 / 2}$ \\
\hline $\mathrm{Nd}(\mathrm{dmhpd})_{3}$ & ${ }^{4} I_{9 / 2} \rightarrow{ }^{2,4} G_{7 / 2.5 / 2}$ & 3.24 & 0.9886 & 1.15 & 0.0755 \\
$\mathrm{Er}(\mathrm{dmhpd})_{3}$ & ${ }^{4} I_{15 / 2} \rightarrow{ }^{4} \mathrm{G}_{11 / 2}$ & 2.48 & 0.9938 & 0.62 & 0.0557 \\
$\mathrm{Nd}(\mathrm{dmod})_{3}$ & ${ }^{4} I_{9 / 2} \rightarrow{ }^{2.4} G_{7 / 2.5 / 2}$ & 3.52 & 0.9879 & 1.22 & 0.0778 \\
$\mathrm{Er}(\mathrm{dmod})_{3}$ & ${ }^{4} I_{15 / 2} \rightarrow{ }^{2} H_{11 / 2}$ & 2.55 & 0.9945 & 0.55 & 0.0524 \\
$\mathrm{Nd}(\mathrm{mphpd})_{3}$ & ${ }^{4} I_{9 / 2} \rightarrow{ }^{2.4} G_{7 / 2.5 / 2}$ & 2.70 & 0.9899 & 1.02 & 0.0711 \\
$\mathrm{Er}(\mathrm{mphpd})_{3}$ & ${ }^{4} I_{15 / 2} \rightarrow{ }^{2} H_{11 / 2}$ & 2.41 & 0.9952 & 0.49 & 0.0049 \\
\hline \hline
\end{tabular}

ході від неодиму до ербію зростає ковалентний внесок у зв'язок Ln$\mathrm{O}$, а в ряду лігандів ступінь ковалентності зростає від диметиоктендіонатних комплексів до метакроїлацетофеноатних.

КОМПЛЕКСЫ НЕОДИМА(ІІІ) И ЭРБИЯ (III) С НОВЫМИ НЕПРЕДЕЛЬНЫМИ $\beta$-ДИКЕТОНАМИ

Н.Б.Иваха ${ }^{1}$, О.С.Бережницқая ${ }^{1,2}$, O.О.Роговцов ${ }^{1}$, О.К.Трунова ${ }^{1}$

${ }^{1}$ Институт общей и неорганической химии им. В.И.Вернадского НАН Украины, просп. Академика Палладина, 32/34, Киев, 03142, Украина

2 Национальный технический університет Украинь “Киевский политехнический інститут имени Игоря Сикорского”, просп. Победы, 37, Киев, 03056, Украина *e-mail: ivakhanadiia@gmail.com

Синтезированы новые координационные соединения $\mathrm{Nd}(\mathrm{III})$ и $\mathrm{Er}$ (III) с $\beta$-дикетонатными лигандами, содержащими непредельный заместитель в $\alpha$-положении хелатного кольца (диметилгептендионом и диметилоктендионом). С использованием физико-химических методов анализа - элементного, ЯМР-, ИК- и электронной спектроскопии, а также термогравиметрического анализа иссле-

наведених даних можна заключити, що в залежності від ненасиченого $\beta$-дикетону зростання ковалентності зв'язку Ln-O у досліджуваних комплексах відбувається у ряду $\operatorname{Ln}(\mathrm{dmod})_{3}$ $<\operatorname{Ln}(\text { dmhpd })_{3}<(\text { mphpd })_{3}$.

ВИСНОВКИ. В роботі синтезовано та досліджено координаційні сполуки $\mathrm{Nd}(\mathrm{III})$ та $\operatorname{Er}(\mathrm{III})$ $3 \beta$-дикетонатними лігандами, що містять ненасичені алкільні та арильні замісники в $\alpha$-положенні хелатного кільця. Встановлено, що склад комплексів відповідає формулам $[\mathrm{Nd}(\beta-$ $\left.\operatorname{dik})_{3} \cdot 2 \mathrm{H}_{2} \mathrm{O}\right] \cdot \mathrm{H}_{2} \mathrm{O}$ та $\mathrm{Er}(\beta-\mathrm{dik})_{3} \cdot 2 \mathrm{H}_{2} \mathrm{O}$, а координаційний поліедр наведених сполук - квадратна антипризма. 3 розрахованих величин параметрів ковалентності випливає, що при пере- дованы состав и строение полученных соединений. Методом ИК-спектроскопии установлено, что лиганды координированы к металлам бидентатноциклически. Результаты термогравиметрического анализа свидетельствуют о том, что исследуемые комплексы нелетучи и разлагаются до оксидов соответствующих металлов, а их координационная сфера дополняется молекулами воды. По форме и положенню полос в электронных спектрах поглощения и спектрах дифузного отражения определено, что для комплексов $\mathrm{Ln}(\beta \text {-dik) })_{3} \cdot n \mathrm{H}_{2} \mathrm{O}(\mathrm{Ln}=\mathrm{Nd}$, $\mathrm{Er}, \beta$-dik $=\mathrm{dmhpd}$, dmod, $n=2-3)$ характерна тетрагональная симметрия ближайшего координационного окружения, координационный полиэдр квадратная антипризма.

К л ю ч е в ы е с л о в а: комплексы, непредельные 
$\beta$-дикетоны, синтез, неодим, ербий, спектральные свойства.

NEODYMIUM (III) AND ERBIUM (III) COMPLEXES WITH NEW UNSATURATED $\beta$-DIKETONES

N.B.Ivakha ${ }^{1} *$, O.S.Berezhnytska ${ }^{1,2}$, O.O.Rogovtsov ${ }^{1}$, O.K.Trunova ${ }^{1}$

${ }^{1}$ V.I.Vernadsky Institute of General and Inorganic Chemistry of National Academy of Sciences of Ukraine, 32/34 Academic Palladin Avenue, Kyiv, 03142, Ukraine

${ }^{2}$ National Technical University of Ukraine "Igor Sikorsky Kyiv Polytechnic Institute”, 37 Peremohy

Avenue, Kyiv, 03056, Ukraine

*e-mail: ivakhanadiia@gmail.com

In this work, the new coordination compounds of $\mathrm{Nd}(\mathrm{III})$ and $\mathrm{Er}$ (III) with $\beta$-diketonate ligands containing an unsaturated substituent at the $\alpha$-position of the chelate ring (dimethylheptendione and dimethyloctendione) were synthesized. The composition and structure of the synthesized compounds were studied using physicochemical methods of analysis such as the elemental, NMR, IR and electron spectroscopy and thermogravimetric analysis. Using IR spectroscopy, it was established that ligands are bidentate-cyclically coordinated to metals. The results of thermogravimetric analysis indicate that the complexes are nonvolatile and decompose to oxides of the corresponding metals, and their coordination sphere is supplemented with water molecules. From the shape and position of the bands in the electronic absorption spectra and diffuse reflection spectra, it was determined that for the complexes $\mathrm{Ln}(\beta \text {-dik })_{3} \cdot n \mathrm{H}_{2} \mathrm{O}(\mathrm{Ln}=$ $\mathrm{Nd}, \mathrm{Er}, \beta$-dik $=$ dmhpd, dmod, $n=2-3$ ) the tetragonal symmetry of the nearest coordination environment; coordination polyhedron is a square antiprism.

When comparing the diffuse reflectance spectra of dimethylheptendionate and dimethyloktendionate complexes among themselves and with the previously studied complexes with methacrylacetophenone, it was noted that the shape of the spectra and the spectral splitting of the bands for the corresponding metals are not significantly different. This allows to conclude, that the coordination environment of the studied $\beta$ diketonate compounds is close.

Based on the band shifts in the electronic spectra, the covalence parameters of the $\mathrm{Ln}-\mathrm{O}$ bond and the oscillator strength were calculated, from which it was also shown that the nature of the substituent affects the covalence parameters, but does not affect the symmetry and structure of the coordination polyhedron.

Based on the studies conducted, the monomeric structure of the synthesized complexes was definitely confirmed. Accordingly, they can be used in further work as monomers in polymerization reactions and the preparation of precursors of luminescent materials.

$\mathrm{K}$ e y w o r d s: complexes, unsaturated $\beta$-diketones, synthesis, neodymium, erbium, spectral properties.

\section{ЛІТЕРАТУРА}

1. Shokova A., Kim J. K., Kovalev V. V. 1,3-Diketones. Synthesis and prproperties // Russian Journal of Organic Chemistry -2015. -51 (6). -P. 755-830.

2. Binnemans $K$ Rare-earth beta-diketonates // Handbook on Physics and Chemistry of Rare Earths. -2005. -35. -P. 107-272.

3. Vigato P.A., Peruzzo V, Tamburini S. The evolution of $\beta$-diketone or $\beta$-diketophenol ligands and related complexes // Coord.Chem.Rev. -2009. -253. -P. 1099-1201.

4. Іваха Н.Б., Бережницька О.С., Трунова О.К. та $i н$. Лантанідні комплекси та полімери алілацетоацетатів $\mathrm{Nd}(\mathrm{III}), \mathrm{Er}(\mathrm{III}), \mathrm{Yb}(\mathrm{III})$ як прекурсори люмінесцентних матеріалів // Укр. хім. журн. -2018. -84, № 3. -С. 3-12.

5. Savchenko I.A., Berezhnytska A.S., Ivakha N.B., Trunova E.K. New nanosized systems based lantanide diketonate complexes for OLEDs // Springer Proceedings in Physics "Nanocomposites, Nanophotonics, Nanobiotechnology, and Applications". -2015. -156. -P. 85-94.

6. Berezhnytska O., Savchenko I., Ivakha N. et al. Synthesis, characterization and luminescent properties of polymer complexes of $\mathrm{Nd}(\mathrm{III})$ with $\beta$ dicarbonyl ligands // Nanoscale Research Letters. -2017. -12. -C. 338.

7. Федоров Я.В. Коодинаційні сполуки $\mathrm{Sm}(\mathrm{III})$ та $\mathrm{Eu}(\mathrm{III}) 3$ ненасиченими $\beta$-дикетонами та металополімери на їх основі: автореф.дис. канд. хіміч. наук. 02.00.01, 2016 p.

8. Патент Украӥни на корисну модель №100305. Спосіб одержання нового нанорозмірного металополімеру неодиму / Бережницька O.C., Трунова О.К, Іваха Н.Б., Савченко І.О., Роговцов О.О., Гудима А.О. Опубл. 2015.

9. Накамото К. Инфракрасная спектроскопия неорганических и координационных соединений. -М.: Мир, 1991.

10. Нехорошков В.П., Камалов Г.Л., Желтвай И.И. О взаимодействии между ИК-спектральными свойствами $\beta$-дикетонатов $3 d$-переходных металлов и их строением. Координац. химия. -1984. -10, №.4. -С. 459-465.

11. Іваха Н.Б., Бережницька О.С., Трунова О.К. та ін. Алілацетоацетатні комплекси $\mathrm{Nd}(\mathrm{III})$, 
$\operatorname{Er}(\mathrm{III}), \mathrm{Yb}(\mathrm{III})$ як прекурсори люмінесцентних матеріалів // Укр. хим. журн. -2015. -81, № 12. -C. 104-110.

12. Pope G.V., Steinbach Y.F., Wagner W.F. Characteristics of the solvates of the rare-earth acetylacetonates // J. Inorg. Nucl. Chem. -1961. -20, № 3/4. -P. 304-313.

13. Мовчан Т.И., Стариков А.Г., Ивлева И.Н. и др. Получение и реакционная способность металлсодержащих мономеров. Сообщение 23. Комплексные соединения переходных металлов на основе метакроилацетона // Изв. АН. Сер. хим. -1992. 3. -С. 694-698.

14. Sinha S.P. Spectroscopic Investigation of Some Neodymium // Spectrochim. Acta. -1966. -22. -P. 57-62.

15. Полуектов Н.С. Спектроскопия в координационной и аналитической химии. -Киев: Наук. думка, 1990.

16. Скопенко В.В., Зуб В.Я. Координаційна хімія. -Практикум, 2002.

17. Choppin G.R., Henrie D.E., Buijus K. Environmental effects of f-f transition Neodimium (III) // Inorg. Chem. -1966. -5. -P. 1743-1749.

18. Іваха Н.Б. Синтез і властивості моно- та полімерних $\beta$-дикарбонільних комплексів $\mathrm{Cu}(\mathrm{II})$, $\mathrm{Ni}(\mathrm{II}), \mathrm{Nd}(\mathrm{III}), \mathrm{Er}(\mathrm{III}) \mathrm{Yb}(\mathrm{III})$ : автореф. дис. канд. хіміч. наук. 02.00.01, 2018 р.

19. Crosby G.A., Whan R.E., Freeman I.I. Spectroscopic studies of rare earth chelates // J. Chem. Phys. -1962. -66. -P. 2493-2499.

20. Костромина Н.А. Комплексонаты редкоземельных элементов. -М.: Наука, 1980.

21. Давиденко Н.К., Яизимирский К.Б. Закономерности смещения полос в спектрах ионов лантанидов при комплексообразовании в раствоpax // Теорет. и эксперимент. химия. -1970. -6, № 5. -С. 620-628.

22. Sinha S.P. Spectroscopic Investigation of Some Neodymium // Spectrochim. Acta. -1966. -22. -P. 57-62.

\section{REFERENCES}

1. Shokova A., Kim J. K., Kovalev V. V. 1,3-Diketones. Synthesis and properties. Russian Journal of Organic Chemistry. 2015. 51. (6): 755.

2. Binnemans K. Rare-earth beta-diketonates. Handbook on Physics and Chemistry of Rare Earths. 2005. 35: 107.

3. Vigato P.A., Peruzzo V, Tamburini S. The evolution of $\beta$-diketone or $\beta$-diketophenol ligands and related complexes. Coord.Chem.Rev. 2009. 253: 1099.
4. Ivakha N.B., Berezhnytska O.S., Trunova O.K., Savchenko I.O., Smola S.S., Rusakova N.V. Lanthanide complexes and polymers of $\mathrm{Nd}(\mathrm{III}), \mathrm{Er}(\mathrm{III})$, $\mathrm{Yb}$ (III) allyacetoacetates, as precursors of luminescent materials. Ukrainian Chemistry Journal. 2018. 84: 3. [in Ukrainian].

5. Savchenko I.A., Berezhnytska A.S., Ivakha N.B., Trunova E.K. New nanosized systems based lantanide diketonate complexes for OLEDs. In book Springer Proceedings in Physics "Nanocomposites, Nanophotonics, Nanobiotechnology, and Applications". 2015. 156: 85.

6. Berezhnytska O., Savchenko I., Ivakha N., Trunova O., Rusakova N., Smola S., Rogovtsov O. Synthesis, characterization and luminescent properties of polymer complexes of $\mathrm{Nd}(\mathrm{III})$ with $\beta$-dicarbonyl ligands. Nanoscale Research Letters. 2017. 12: 338.

7. Fedorov Ya.V. Ph.D(Chem.) Thesis. (Kyiv, 2016). [in Ukrainian].

8. Patent of Ukraine on the utility model №100305. Berezhnytska O.S., Trunova O.K., Ivakha N.B., Savchenko I.O., Rogovtsov O.O., Gudyma A.O. A method for obtaining a new nano neodymium metalpolymer. 2015. [in Ukrainian].

9. Nakamoto K. Infrared Spectroscopy of Inorganic and Coordination Compounds. (Moscow: Mir, 1991). [in Russian].

10. Nehoroshkov V.P., Kamalov G.L., Geltvaiy I.I. About the relationship between IR spectral properties of $\beta$-diketonates $3 d$-transition metals and their structure. Russ. J.Coord.Chem. 1984. 10. (4): 459. [in Russian].

11. Ivakha N.B., Berezhnytska O.S., Trunova O.K., Savchenko I.O., Smola S.S., Zheleznova L.I. Allylacetoacetate complexes of $\mathrm{Nd}(\mathrm{III}), \mathrm{Er}(\mathrm{III})$, $\mathrm{Yb}$ (III) as precursors for luminescent materials. Ukrainian Chemistry Journal. 2015. 81. (12): 104. [in Ukrainian].

12. Pope G.V., Steinbach Y.F., Wagner W.F. Characteristics of the solvates of the rare-earth acetylacetonates..J. Inorg. Nucl. Chem. 1961. 20 (3-4): 304.

13. Movchan T.I., Starikov A.G., Ivleva I.N., Voloshanovsky I.S., Pomogailo A.D. Preparation and reactivity of metal-containing monomers. Communication 23. Complex compounds of transition metals based on methacrylacetone. Bul. Academy of Sciences, ser.chem. 1992. 3: 694. [in Russian].

14. Sinha S.P. Spectroscopic Investigation of Some Neodymium. Spectrochim. Acta. 1966. 22: 57.

15. Poluektov N.S. Spectroscopy in coordination and analytical chemistry. (Kyiv: Naukova dumka, 1990). [in Russian]. 
16. Skopenko V.V., Zub V.Ya. Coordination chemistry. (Workshop, 2002). [in Ukrainian].

17. Choppin G.R., Henrie D.E., Buijus K. Environmental effects of $f-f$ transition Neodimium (III). Inorg. Chem. 1966. 5: 1743.

18. Ivakha N.B. Іваха Н.Б. Ph.D(Chem.) Thesis. (Kyiv, 2018). [in Ukrainian].

19. Crosby G.A., Whan R.E., Freeman I.I. Spectroscopic studies of rare earth chelates. J. Chem.
Phys. 1962. 66: 2493.

20. Kostromina N.A. Complexonates of rare-earth elements. (Moscow: Nauka, 1980). [in Russian].

21. Davydenko N.K., Yatsymirskiy K.B. The regularities of banding in the spectra of lanthanide ions at complexing in solutions. TEC. 1970. 6. (5): 620. [in Russian].

22. Sinha S.P. Spectroscopic Investigation of Some Neodymium. Spectrochim. Acta. 1966. 22: 57.

Надійшла 06.06.2019 